DOI: http://dx.doi.org/10.33846/hn41007

http://heanoti.com/index.php/hn

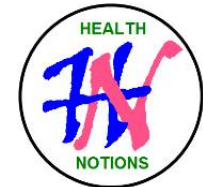

RESEARCH ARTICLE

URL of this article: http://heanoti.com/index.php/hn/article/view/hn41007

\title{
Implementation of Research Based Learning Development in Maternity Nursing Course
}

\author{
Indah Lestari $^{1(\mathrm{CA})}$, Noer Saudah ${ }^{2}$, Catur Prasatia Lukita Dewi ${ }^{3}$ \\ ${ }^{1(\mathrm{CA})}$ Department of Maternity Nursing, Faculty of Nursing, STIKes Bina Sehat PPNI Mojokerto, Indonesia; \\ ns.indah@yahoo.com (Corresponding Author) \\ ${ }^{2}$ Department of Maternity Nursing, Faculty of Nursing, STIKes Bina Sehat PPNI Mojokerto, Indonesia; \\ saudah_noer@yahoo.co.id \\ ${ }^{3}$ Department of Maternity Nursing, Faculty of Nursing, STIKes Bina Sehat PPNI Mojokerto, Indonesia; \\ humeyra.dewi@gmail.com
}

\begin{abstract}
There have been many learning innovations that have been carried out by lecturers, but there are still many that only emphasize the low-level cognitive domains and not the high-level cognitive domains (analysis, synthesis, evaluation, and creation), the affective and psychomotor domains. The learning model has not been used many facilitate students to learn actively. As a result, learning is more dominated lecturers so that student activities are less than optimal. The purpose of this study is to develop learning tools and textbooks maternity nursing courses with a research-based learning approach. The resulting product are (1) learning tools in maternity nursing and (2) textbooks with research-based applications. The research was conducted on 40 undergraduate students of STIKes Bina Sehat PPNI Mojokerto, who carried out the academic learning process of maternity nursing. The method used refers to the 7 stages of the researchbased learning process, with the validation of consultants and education experts. The main framework above is used as a basis for developing learning tools. Then the expert test of theoretical validity was carried out on the implementation of the RBL learning tool, with the result that the value of $r=0.909$ (high reliability). The test results are widespread, not much different from the expert test results. While research-based textbooks are the results of research outputs, used as a guide for students to be able to build critical thinking, analysis and structure based on evidence.
\end{abstract}

Keywords: research based learning; learning tools; maternity nursing

\section{INTRODUCTION}

The educational strategy is an important indicator that is capable of changing the human thoughts from less understand to be more comprehend the matter occured as a whole. The improvement of comprehension capacity were in cognitive, affective, and psychomotor domain. Students is intellectuals positioned as 5\% of nation's population in Indonesia which obliged to improve self quality particularly in order to improve the quality of nation in general with the knowledge learned during the education on campus in accordance with certain scientific fields ${ }^{(1)}$.

Research Based Learning (RBL) is a learning model that leads to the activities of analysis, synthesis, and evaluation as well as improving the ability of students and lecturers in terms of assimilation and application of knowledge. Lockwood, Research- based learning is a system of intruction which used an authentic-learning, problem - solving, cooperative learning, hands on, and inquiry discovery approach, guided by a constructivist philosophy. Its usefulness had been recognized for many decades but "research in classroom" had not been adopted as a teaching method by many $y^{(2)}$. Research Based Learning - RBL can strengthen students to be active in learning. This is in line with disclosed According to (Arifin, 2010), in Research Based Learning - RBL there can make students able; 1) have a strong understanding of basic concepts and methodology, 2) can solve problems creatively, logically and systematically, 3) have a scientific attitude that is always looking for the truth, is open, and honest. Students are expected to have competent communication, technical and analytical skills to adapt, work in groups and be competitive. Model Research Based Learning - RBL can be used as a learning reform in higher education to improve the quality of learning and graduates who are ready to face the challenges of the 21st century; work ethic, collaboration, good communication, social responsibility, critical thinking and problem solving ${ }^{(3)}$. RBL gives students the opportunity to practice metacognitive abilities and encourage critical thinking, make predictions, propose causative factors, and present constructive arguments ${ }^{(4)}$.

These methods of learning are student-focused, which allow for active learning and better understanding and retention of knowledge. These facilitate students develop life skills that enhance content knowledge, foster the development of communication, problem solving, critical thinking, collaboration, and self-directed learning skills. 
Through these approaches students are positioned to optimally act resolving real-world experiences. These approaches represent a paradigm shift from traditional teaching and learning philosophy, which is primarily lecture based. The constructs for teaching through these methods are very different from traditional classroom or lecture teaching and often requires more preparation time and resources to support small group learning. Under these methods teacher presents students a problem, not lectures or assignments or exercises. Since students are not handed "content", the learning becomes active in the sense that students discover and work with content that you determine to be necessary to solve the problem. In the process the teacher acts as facilitator and mentor, rather than a source of "solutions." (5)

The purpose of the study is to developing learning tools and textbooks based on research learning.

\section{METHODS}

The research was conducted on undergraduate students of STIKes Bina Sehat PPNI Mojokerto who carried out the academic learning process of maternity nursing starting from May 2020 to September 2020 (cognitive learning in odd semesters was advanced, as an adjustment to pandemic conditions). This study was designed using a research and development approach. The products to be developed are in the form of learning tools and teaching materials. Data in the form of the results of filling and validator notes on the validation sheet instrument of content quality, linguistic presentation, and graphic of course materials were collected using validation techniques (from experts). Instrument in the form of a checklist of the accuracy of learning activities compared to the model framework and the suitability sheet for the roles of lecturers and students. The seven stages of this research include: (a) Research and Information Gathering Stage to collect information through literature review. (b) Planning Stage. (1) collecting maternity nursing theory and research-based learning theory, (2) reviewing the theory of teaching materials to be developed, (3) making RPS, (4) planning the systematics of course material, (5) analyzing the systematics of course material (c) Stage Pre Plan Products. Develop the initial product form / design of the developed course material. (d) Conducting Test Stage by applying course material developed to students, while consulting with experts, through textbook validation. (e) Stage of Performing Product Revisions includes: (1) Reviewing input from experts and practitioners; (2) Rearrangement of the developed design prototype based on the results of initial field tests. (f) Final Product Revision Stage. (g) The dissemination stage by: (1) making research reports, (2) publishing scientific journals.

\section{RESULTS}

Table 1. The main framework for developing research-based learning tools

\begin{tabular}{|c|c|c|c|}
\hline No & Stucture & Elements & Description \\
\hline 1. & Identity & & \\
\hline 2. & Indicator & & \\
\hline \multirow[t]{5}{*}{3.} & Learning objectives & & \\
\hline & A. Cognitive product & 4,6 & $\begin{array}{ll}\text { a. } & \text { Applying to solve real research problems } \\
\text { b. } & \text { Research results (part of lecturer research) }\end{array}$ \\
\hline & B. Cognitive process & $\begin{array}{l}2,3,4 \\
5,6\end{array}$ & $\begin{array}{l}\text { a. Discuss findings Recent research } \\
\text { b. Improve understanding current research policies and practices. } \\
\text { c. Deliver research issues in accordance with the subject matter. } \\
\text { d. Improve understanding about research methodology. } \\
\text { e. Designing teaching materials. } \\
\text { f. Conduct research together; } \\
\text { g. Make visits to research centers }\end{array}$ \\
\hline & C. Psychomotor & 5 & $\begin{array}{l}\text { a. Can use tools related to research activities such as; (1) calculating instruments, (2) } \\
\text { measuring instruments, and (3) materials. } \\
\text { b. Result presentation technique. }\end{array}$ \\
\hline & D. Affective & $5,7,8$ & $\begin{array}{ll}\text { a. } & \text { Participation in research activities. } \\
\text { b. } & \text { Participation in activities research } \\
\text { c. } & \text { Award of findings research, respect for other views, is tolerant of uncertainty }\end{array}$ \\
\hline 4. & Learning materials & 1 & Enrich teaching materials with research results from lecturers and college student. \\
\hline 5. & $\begin{array}{l}\text { Learning models and } \\
\text { methods }\end{array}$ & & \\
\hline 6. & Learning Resources & $1,2,3,6$ & $\begin{array}{l}\text { a. Enrich teaching materials with research results from lecturers and students. } \\
\text { b. Recent research findings } \\
\text { c. Results and reports of research occurring in the community. } \\
\text { d. Research centers. } \\
\text { e. Researcher Interview. }\end{array}$ \\
\hline 7. & Tools and Materials & 5 & Using tools such as (1) calculators, (2) computers, (3) data analysis programs. \\
\hline \multirow[t]{3}{*}{8.} & Learning Activities & & \\
\hline & 1. Introduction & 1,3 & $\begin{array}{l}\text { a. Apperception, contains the controversy of research results. } \\
\text { b. Motivate doing research. } \\
\text { c. Delivering the objectives of learning. }\end{array}$ \\
\hline & 2. $\quad$ Core & $\begin{array}{l}2,3,4 \\
5,6,7,8\end{array}$ & $\begin{array}{l}\text { a. discuss the findings of recent research. } \\
\text { b. convey current research issues, which are in accordance with the subject matter. } \\
\text { c. compare research reports and reports that occur in the community. } \\
\text { d. analyze the research methodology and the arguments relating to the research } \\
\text { findings presented in research journals. } \\
\text { e. conduct literature studies on the development of the latest knowledge in accordance } \\
\text { with the subject. } \\
\text { f. Increase students' understanding of research methodology. } \\
\text { g. Designing teaching material by including research methodology on the subject, so } \\
\text { that students can apply it to solve real research problems. }\end{array}$ \\
\hline
\end{tabular}




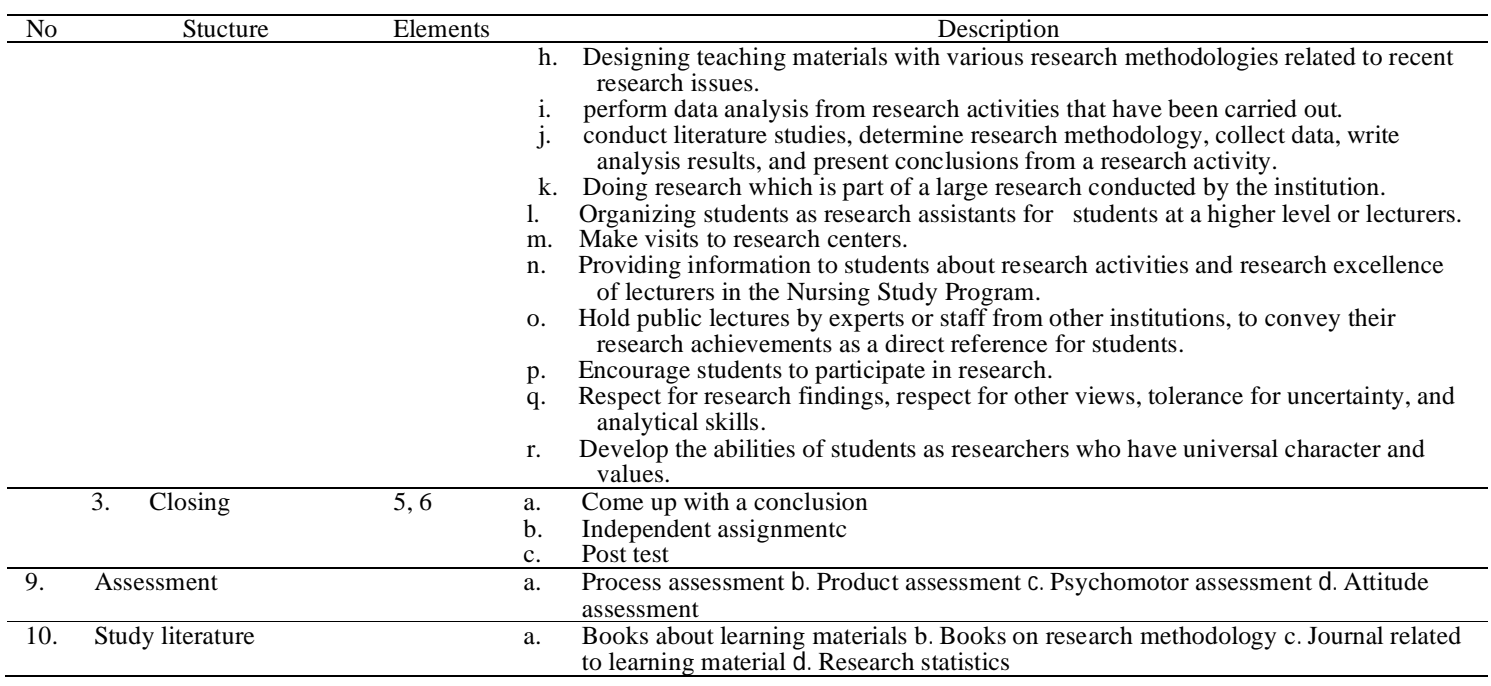

The main framework above is used as a basis for developing learning tools. Then the expert test of theoretical validity was carried out on the implementation of the RBL learning tool, with the result that the value of $r=0.909$ (high reliability). The test results are widespread, not much different from the expert test results. While research-based textbooks are the results of research outputs, used as a guide for students to be able to build critical thinking, analysis and structure based on evidence.

\section{DISCUSSION}

Research-based learning model (RBL) Lizelwati (2014) and Gravin (Endriani, 2014) is a process of learning and building their own knowledge by allowing students to train their abilities through a series of activities observation and analysis, while Srikoon, et al., (2014) revealed that in the process of learning combines four aspects of understanding that is to formulate problems, analyze, outcome and communicate it. Steps in research-based learning according to ${ }^{(6)}$, Chrystis (2015) are 1) stage of exposure, 2) experience stage, 3) stage of information convey (capstone). The advantages and benefits of a research-based learning model according to Hoskins and Mitchell (2005), Chamdani, et al., (2015) that can increase learning motivation to be more active, have learning independence, high curiousity, critical, creative so as to improve learning outcomes. ${ }^{(7),(8),(9)}$

Research-based learning is a student centered learning model that integrates research into the learning process. The learning process is the implementation of the combination of research and meaningful learning. Research-based learning is multifaceted, referring to various learning methods, so that all students' learning outcomes come from a simple research that they do, for example through experiments and field studies ${ }^{(10)}$. Research-based learning provides opportunities for students to formulate problems, review theories, construct hypotheses, collect data, analyze data, and conclude the results obtained. Poonpan (2005) states that "Researchbased learning is an effective way to change students' learning and to practice about how to learn by doing. Research-based learning is a system of instruction which uses an authentic learning, problem solving, cooperative learning, handson, and inquiry discovery approach, guided by a constructivist philosophy". Prahmana (2007) defines research-based learning as a model of learning which is authentic, problem solving, cooperative, contextual (hands on and minds on), and inquiry discovery approach based on a constructivist philosophy, so that students can improve their learning independence, critical thinking skills, creativity and communication skills. Research is an activity to discover, develop and test the truth of knowledge and summarize the findings obtained ${ }^{(11)}$.

The competencies acquired by students after research-based learning are: (a) to have an understanding of the concepts of physics and research methods; (b) to be able to solve problems creatively, logically and systematically; and (c) to have a scientific attitude that always seeks truth, and be open and honest ${ }^{(12)}$. The results of relevant research that has been done shows that the application of research-based learning that is life skill-oriented can increase the activity and the mastery of the essential concepts of university students in thermodynamics. The use of research-based student worksheets in physics learning is effective in improving the competence of students. Research-based learning with a scientific approach to effectively improve science process skills of students ${ }^{(13)}$.

Critical thinking is one of the more complex forms of thinking activity which involves activities in analyzing more specific ideas, differentiating, choosing, identifying, assessing, and developing them in a more perfect direction. Critical thinking is a process and an ability to make rational decisions. Ennis (1996) proposes that the test to measure critical thinking skills is developed from five indicators, namely: (1) analysis, measuring the ability to understand the meaning of varied data, experience, and assessment; (2) Evaluation, measuring the ability to judge information and state the results of one's reasoning; (3) Inference, measuring the ability to identify the information needed to make conclusion; (4) Deductive reasoning, measuring one's ability which is started from general idea or a premise to a specific conclusion; (5) Inductive reasoning, measuring one's ability which is started from a premise or an application related to knowledge or an experience to a general conclusion ${ }^{(9),(14)}$.

There are several strategies in integrating learning and research empirically: 1) enriching teaching materials with the results of educators' research, 2) using latest research findings and tracking history, 3) enriching learning activities with 
contemporary issues, 4) teaching material research methods in learning process, 5) enriching the learning process with research activities on a small scale, 6) enriching the learning process by involving students in activities, 7) enriching the learning process by encouraging students to feel, 8) enrich the learning process with values that must be possessed by researchers ${ }^{(8)}$.

Research-based learning can improve students' skills in solving problems, thinking critically, and finding knowledge. The research-based learning is effective in improving the mastery of physics concepts and students' generic abilities. Researchbased learning can improve the science process skills in physics. Research-based physics learning with scientific approach is effective in improving students' science literacy. Research-based learning can increase students' curiosity about the subject matter ${ }^{(15)}$. The inquiry methods used in researchbased learning can improve cognitive skills, critical thinking skills, scientific work skills, and scientific attitudes of the students ${ }^{(16)}$. The application of research-based learning could increase the activity, the skill and the knowledge of students in science lessons. Irianti in her research concluded that the SETS approach was effective for teaching students in physics learning on camera and periscope material. SETS-based science learning can improve the learning outcomes, the process skills, and the activeness on every meeting ${ }^{(17)}$. Research-based learning model with SETS approach was implemented in the laboratory. The importance of laboratory activities to understand the concepts of physics for students is proposed by Ivins and Raghubir. According to Ivins ${ }^{(18)}$. Laboratory activities are more effective in helping students learn physics than learning from discussions. Raghubir ${ }^{(19)}$ found out that students showed high level of cognitive ability when they actually acquired knowledge through laboratory activities rather than using the laboratory to verify the theories that had been studied. The inquiry practicum activities are more challenging for students in finding the concept of physics than the verification activities. The inquiry practicum activities could improve students' skills in conducting practicum. ${ }^{(20)}$ The inquiry practicum activities could improve students' skills in thinking logically, solving problems, and give impressive experience of laboratory activity. Guided Inqury-based practicum learning can improve the critical thinking skills of students ${ }^{(21)}$.

\section{CONCLUSION}

Research-based learning model is considered feasible by experts to be implemented in the learning process. Textbooks are the results of research. The development of research-based textbooks, from one of the subject matter of the course, is declared appropriate and in accordance with basic competencies and indicators, to help improve students' critical thinking, analytical and structured skills.

\section{REFERENCES}

1. Hung W. The 3C3R Model : A Conceptual Framework for Designing Problems in PBL. 2006;1(1):5-22.

2. Komala R, Faculty NS. Indonesian Journal of Science and Education. 2018;2(2):168-73.

3. Bidang J, Dasar P. Jurnal Bidang Pendidikan Dasar (JBPD), Vol.2 No.2 Juni 2018.

4. Hendrowati TY. Pembentukan Pengetahuan Lingkaran Melalui Pembelajaran Asimilasi \& Akomodasi Teori. 2015;1(1):1-16.

5. Granjeiro ÉM. Research-based teaching-learning method: a strategy to motivate and engage students in human physiology classes. 2020;553-6.

6. That RS, Teachers A, Know S. Principles of Instruction. 2012;12-20.

7. Brew A, Jewell E. International Journal for Academic Enhancing quality learning through experiences of research-based learning: implications for academic development. (May 2015):37-41.

8. Ak O, Özkarde R. The Effects of Problem-Based Active Learning in Science Education on Students Academic Achievement, Attitude and Concept. 2007;3(1):71-81.

9. Dornan T, Boshuizen H, King N, Scherpbier A. workplace learning Experience-based learning: a model linking the processes and outcomes of medical students ' workplace learning. 2007;84-91.

10. Siegel C. Implementing a Research-Based. 2010;(May 2015):37-41.

11. Cant RP, Cooper SJ. Simulation-based learning in nurse education: systematic review. 2009;(Cioffi 2001):3-15.

12. Clement J. International Journal of Model based learning as a key research area for science education. 2010;37-41.

13. The Development Of Research-Based Learning Model With Science, Environment Technology And Society. Jurnal Pendidikan IPA Indonesia. 2017;6(2):318-25.

14. Thompson C, Dphil BA. The accessibility of research-based knowledge for nurses in UK acute care settings. 2001;

15. Hmelo-silver CE, Barrows HS, Hmelo-silver CE, Barrows HS. Goals and Strategies of a Problem-based Learning Facilitator. 2006;1(1):5-22.

16. Jacobsen M, Brown B, Eaton SE, Simmons M. Graduate students' research-based learning experiences in an online Master of Education program. 2018;15(4).

17. More L, How A, Used RKG. Working Paper Learning More About How.

18. Of P, On MPE. The Development Of Research-Based Learning Model And Journal As For Graduate Students' Scientific. 2018;8(5):500-5.

19. Seel NM. Model-based learning: a synthesis of theory and research Model-based Learning A Synthesis of Theory and Research. 2017.

20. Saxena P, Gangwar N. Research Based Learning. 2018;(April 2017).

21. Resbiantoro G, Efisiensi A. Pembelajaran berbasis riset sebagai pondasi menuju research university. 